\title{
Chia Seeds Storage in Different Environmental Conditions and Packages
}

\section{Claudia Kely Pires de Mattos Sorana, Fernanda Brito Cardoso, Carlos Henrique Queiroz Rego, Ana Carina da Silva Cândido, Charline Zaratin Alves*}

Federal University of Mato Grosso do Sul, UFMS, Chapadão do Sul, Mato Grosso do Sul, Brazil

Email: *charline.alves@ufms.br

How to cite this paper: Sorana, C.K.P.M., Cardoso, F.B., Rego, C.H.Q., Cândido, A.C.S. and Alves, C.Z. (2018) Chia Seeds Storage in Different Environmental Conditions and Packages. American Journal of Plant Sciences, 9, 74-82.

https://doi.org/10.4236/ajps.2018.91007

Received: December 21, 2017

Accepted: January 14, 2018

Published: January 17, 2018

Copyright $\odot 2018$ by authors and Scientific Research Publishing Inc. This work is licensed under the Creative Commons Attribution International License (CC BY 4.0).

http://creativecommons.org/licenses/by/4.0/

\section{Open Access}

\begin{abstract}
In general, seeds are not used immediately after harvesting. For this reason, they have to be stored for future use, which requires the maintenance of their viability during the storage time by applying the appropriate conservation technology for each species. This study aimed to evaluate whether package and environmental conditions interfere with the physiological quality of chia seeds (Salvia hispanica L.) stored for 12 months. The experiment consisted of a completely randomized design in a $3 \times 3 \times 4$ factorial scheme, with four replications, using three packages, three storage environments, and four storage times. After each storage time, seeds were subject to germination and vigor tests (emergence and electrical conductivity). Chia seeds can be stored in a cold or dry chamber, in plastic, glass, or paper containers, for 12 months, without hindering seeds physiological quality.
\end{abstract}

\section{Keywords}

Conservation, Storage, Physiological Quality, Salvia hispanica

\section{Introduction}

Salvia hispanica L. (Lamiaceae), known as chia, is an annual cycle herbaceous plant, native to the midwestern region of Mexico and northern Guatemala [1] [2]. Its seeds are known for their antioxidant properties, dietary fiber, and $\alpha$-linolenic acid contents, which help prevent several diseases [3] [4]. Chia seeds have stood out as a nutrient source for the food industry owing to their benefits to human health [4] [5]. Recently, the species has aroused the interest of Brazilian producers as an alternative for the second harvest cultivation due to its simple management and high grain yield expectation. However, seed quality as- 
sessment is fundamental to the success of any culture. In the case of chia seeds, information on seed quality is still scarce.

In most cases, seeds are not used immediately after harvesting. Instead, they are stored for future use, requiring the application of appropriate conservation technology for each species. Although seeds quality cannot be improved during this period, a good storage condition influences seeds survival and longevity and assists in keeping them viable [6].

The deterioration process is linked to the chemical composition of the seeds [7]. However, seeds longevity during storage depends on factors such as water content, environmental conditions, package, microorganisms, among others [8]. The most evident physiological symptoms of seed deterioration appear during germination and seedling initial development due to the disruption of the membrane system as a consequence of the attack of free radicals on the chemical compounds of the membrane [9]. Thus, seeds stored under adequate conditions of temperature and relative air humidity maintain their physiological potential, which reduces the respiratory activity and decreases the deterioration process [8].

Although the choice of the package for seed storage seems easy, this decision depends on the conditions of the storage environment and the characteristics of availability of each package. Therefore, the knowledge of the influence of different types of seed storage conditions and times is fundamental [10]. Thus, this study aimed to evaluate if the package and environmental conditions interfere with the physiological quality of chia seeds stored for 12 months.

\section{Materials and Methods}

The experiment was carried out with chia seeds purchased from producers from the region of Chapadão do Sul, Mato Grosso do Sul (MS), Brazil. The experiment consisted of a completely randomized design in a $3 \times 3 \times 4$ factorial scheme, with four replications. Treatments comprised three types of package (glass, plastic, and paper; impermeable, semipermeable, and permeable, respectively); three storage environments [cold chamber $\left(8^{\circ} \mathrm{C} \pm 2^{\circ} \mathrm{C}\right.$ and $60 \%$ relative humidity); ambient conditions with no temperature or relative humidity control (annual average: $25^{\circ} \mathrm{C}$ and $50 \%$ relative humidity); and dry chamber $\left(17^{\circ} \mathrm{C} \pm\right.$ $2^{\circ} \mathrm{C}$ and $50 \%$ relative humidity)]; and four storage times (zero, four, eight, and 12 months). Each combination had $500 \mathrm{~g}$ of seeds. After each storage time, seeds water content was determined, and germination and vigor tests were performed (emergence and electrical conductivity).

The water content was determined using the oven drying method at $105^{\circ} \mathrm{C} \pm$ $3^{\circ} \mathrm{C}$ for 24 hours, with two replications, containing approximately $2 \mathrm{~g}$ for each lot [11]. For the germination test, seeds were arranged on the substrate on paper in gerbox boxes, with four replications of 50 seeds, maintained at $25^{\circ} \mathrm{C}$, with continuous light. Germination count was carried out at seven days after test installation, using the emission of the primary root greater than $2.0 \mathrm{~mm}$ in length 
as a criterion.

The emergence test consisted of four replications of 50 seeds, in each treatment, which were sown in 200-cell expanded polystyrene trays, containing commercial substrate, in a greenhouse. Germination count was performed at seven days after sowing. The electrical conductivity test was carried out using four replications of 50 seeds originated from physically pure seeds, which were weighed and placed in plastic cups containing $25.0 \mathrm{~mL}$ of distilled water, and kept at $25^{\circ} \mathrm{C}$. After 24 hours, the conductivity readings revealed the mean values obtained for each treatment, expressed as $\mu \mathrm{S} \cdot \mathrm{cm}^{-1} \cdot \mathrm{g}^{-1}$.

The material was subject to statistical analysis by the Tukey's test at 5\% probability, using means comparison for package types and environmental conditions, and polynomial regression analysis for storage times.

\section{Results and Discussion}

The water content of chia seeds in all the evaluated storage and package presented slight variations during storage. The lowest change in the water content was observed in the glass and paper package under the three storage conditions (Figure 1). The package $\times$ environment $\times$ storage time interaction was significant for all the evaluated parameters. The increase in the storage time negatively affected the germination and vigor of chia seeds.

Chia seeds stored in a cold chamber (Figure 2(a)) and dry chamber (Figure 2(c)) showed a germination reduction from the fourth month for the three packages used. However, at the end of 12 months, germination remained above $80 \%$, evidencing that the storage at low temperatures and the control of the relative humidity of the cold and dry chambers resulted in a better seeds conservation, minimizing the deterioration process. Low temperatures reduced chemical reactions speed and consequently respiration speed, which benefited seeds conservation [8]. Reference [12] concluded that the seeds of carqueja (Baccharistrimera (Less) DC.) stored in a refrigerator presented better conservation regardless of the package used.

Seeds stored under uncontrolled ambient conditions (Figure 2(b)) had germination reduction over the storage time. This reduction was lower in the glass and plastic packages. At the end of 12-months, germination was still above $70 \%$. However, a marked germination decrease was observed for the paper package, resulting in values of $30 \%$ at the end of the storage time. Reference [13] reported similar results for catanduva seeds (Piptadenia moniliformis Benth.), which showed lower germination when stored in the paper package than in the plastic and glass packages, maintaining this behavior up to 150 days of storage under uncontrolled ambient conditions.

Seed deterioration during storage alters the biochemical and physiological processes due to the production of reactive oxygen species, changing the structure of antioxidant enzymes. This fact reduces seeds quality as a consequence of the exhaustion of their reserves, leading to the progressive decline of the percentage of normal seedlings and the sharp decrease in seed viability [14]. 


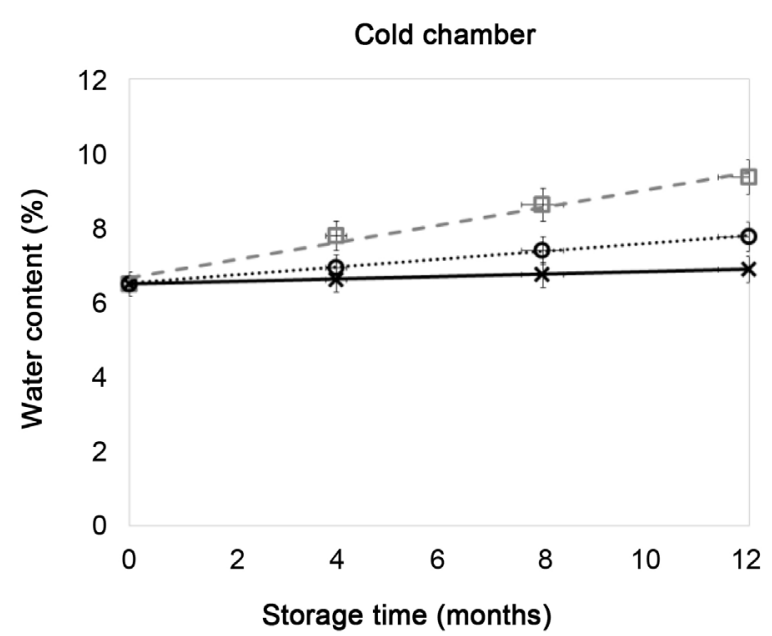

(a)

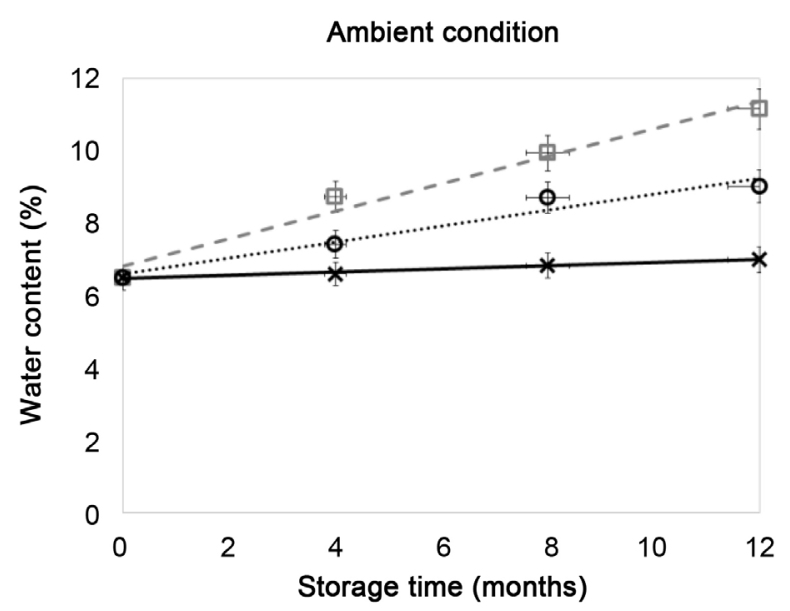

(b)

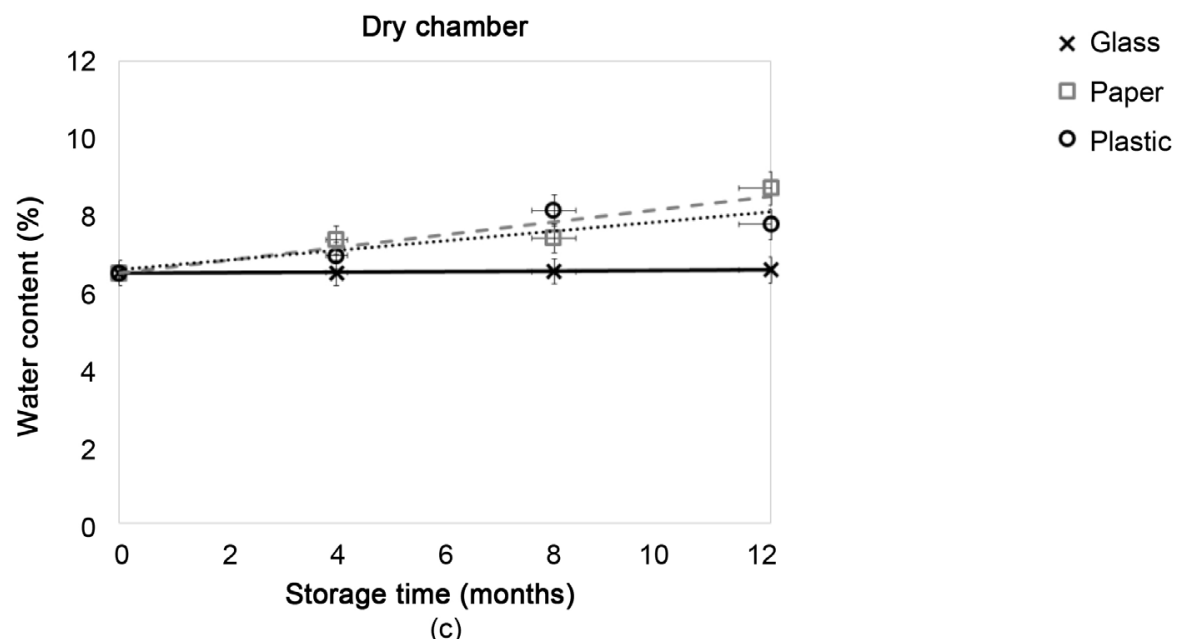

Figure 1. Water content of chia seeds stored in cold chamber (a), under ambient conditions (b) and dry chamber (c) in three packages for a 12-month storage time.

Seeds stored in cold (Figure 3(a)) and dry (Figure 3(c)) chambers presented a decrease in seeds emergence over the storage time. However, germination percentage was even lower (Figure 3). After 12-months of storage in the cold chamber (Figure 3(a)), seeds stored in paper and plastic packages presented $70 \%$ of emergence, while seeds stored in the glass package presented higher values. For the dry chamber (Figure 3(c)), the plastic package provided $70 \%$ of emergence and the paper and glass packages resulted in $60 \%$ of emergence. Under uncontrolled ambient conditions (Figure 3(b)), seeds emergence also decreased over time; nevertheless, these values were less pronounced for the plastic and glass packages, with $60 \%$ of emergence after 12 -months of storage. Seeds stored in the paper package had the worst results, presenting a marked reduction in seeds emergence from the fourth month, reaching less than $10 \%$ of emergence at the end of 12-months. Reference [15] reported similar results for seedlings emergence of Amburana cearenses Smith seeds stored in a paper bag and maintained under uncontrolled ambient conditions. 


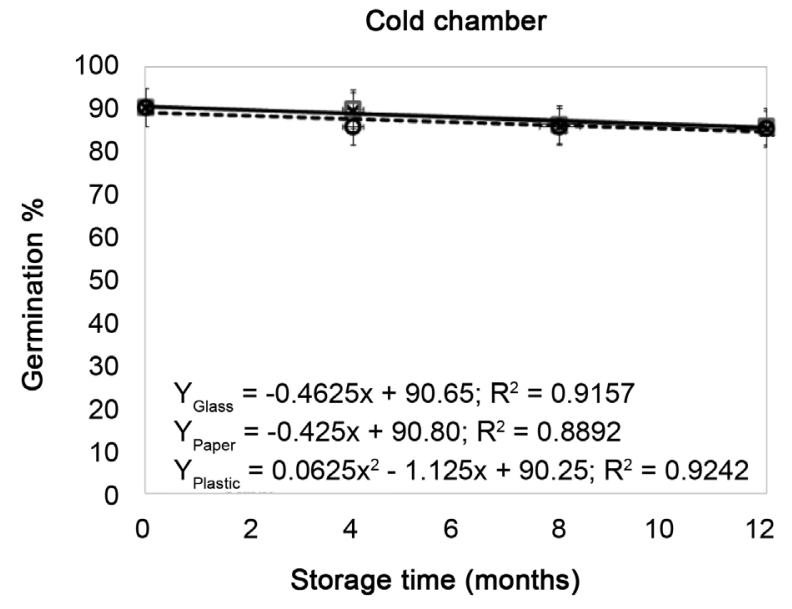

(a)

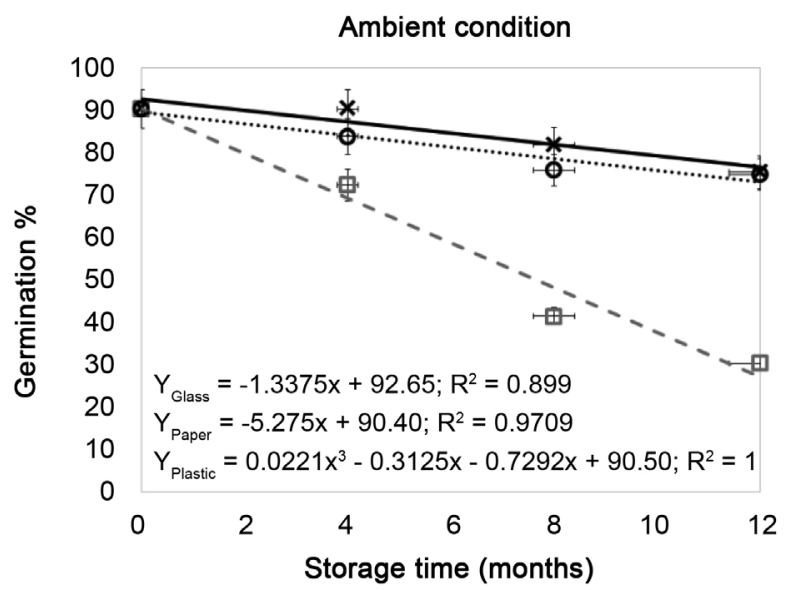

(b)

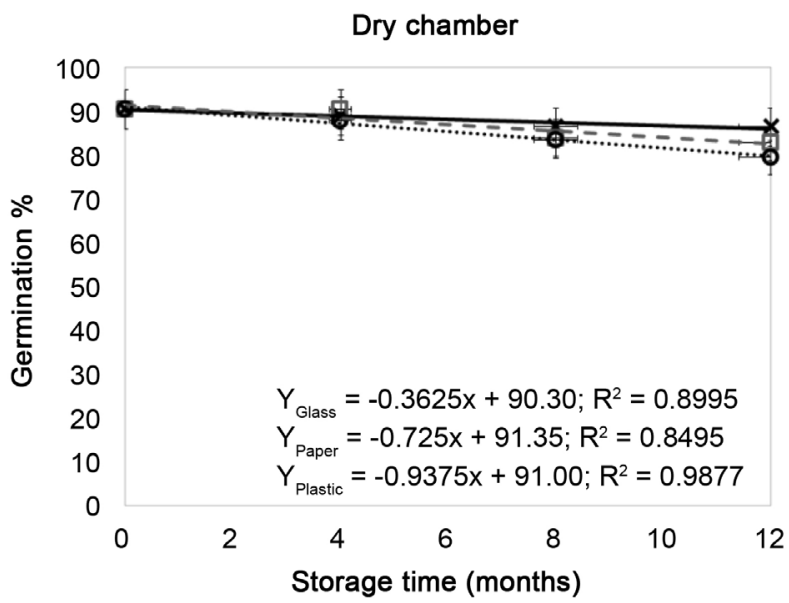

$\times$ Glass

$\square$ Paper

- Plastic

(c)

Figure 2. Percentage of germination of chia seeds stored in three environments and three packages for a 12-month storage time.

Electrolytes leaching of chia seeds, measured by the electrical conductivity of the imbibition water (Figure 4), increased over time for seeds stored in a cold chamber (Figure 4(a)), in all the evaluated packages, especially for the glass package. When stored in a dry chamber (Figure $4(\mathrm{c})$ ), seeds presented a similar increase in the conductivity values for the three packages, proving that the seeds vigor decreases with the storage time. However, the increase in conductivity values in these two storage environments was not too sharp.

Chia seeds stored under uncontrolled ambient conditions (Figure 4(b)) presented higher values of electrical conductivity. From the fourth month of storage, these values increased, with a higher leaching and consequently higher loss of cell membranes regulatory capacity. Again, the plastic and glass packages provided lower electrolyte increase when compared with the paper package, resulting in higher values of electrical conductivity and less vigorous seeds. Reference [16] stated that high temperatures during the storage $\left(20^{\circ} \mathrm{C}\right.$ and $\left.25^{\circ} \mathrm{C}\right)$ led to changes in the values of electrical conductivity during storage times, revealing an increase in leachate losses over time. The effects of environmental conditions 


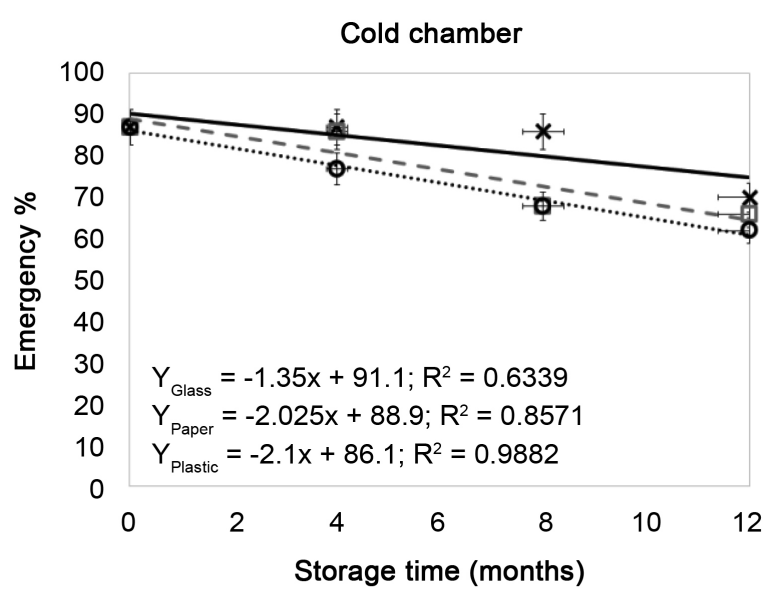

(a)

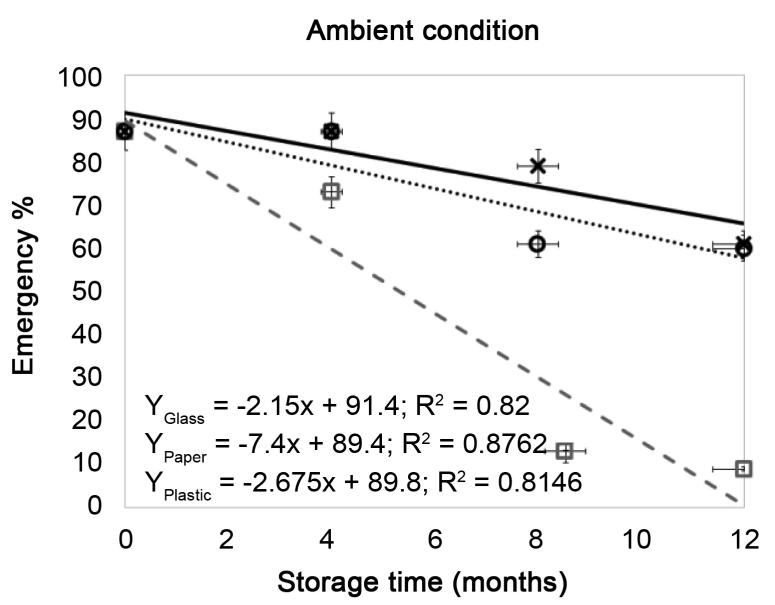

(b)

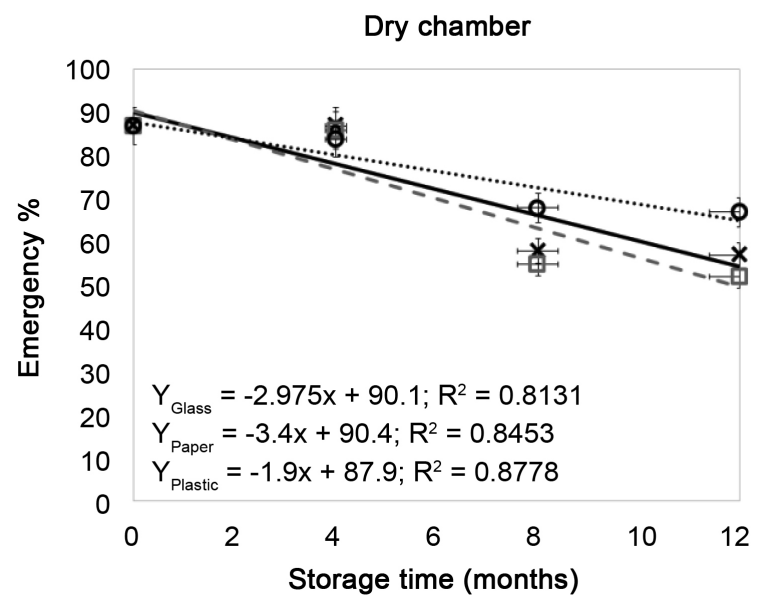

$\times$ Glass

$\square$ Paper

- Plastic

(c)

Figure 3. Seedlings emergence of chia seeds stored in three environments and three packages for a 12-month storage time.

of temperature and relative humidity on the seed performance during storage depend on the traits of each species. These effects are related to the chemical composition of the seed, such as proteins, lipids, and carbohydrates, especially starch [14].

In general, chia seeds germination percentage had a small decrease with storage time under controlled conditions of cold and dry chambers, regardless of the package, as well as under uncontrolled ambient conditions in the glass and plastic packages. Certainly, the combination of the low temperature and the controlled relative air humidity provided more favorable conditions, which minimized the seeds deterioration rate. Results showed that storage under cold and dry chamber conditions maintained the chia seed germination capacity for longer, even at lower levels than that observed at the beginning of the experiment.

The analysis of the storage time revealed a reduction in germination and seed vigor over time. The paper package is not indicated for storage under uncontrolled ambient conditions for being harmful to the maintenance of chia seeds 


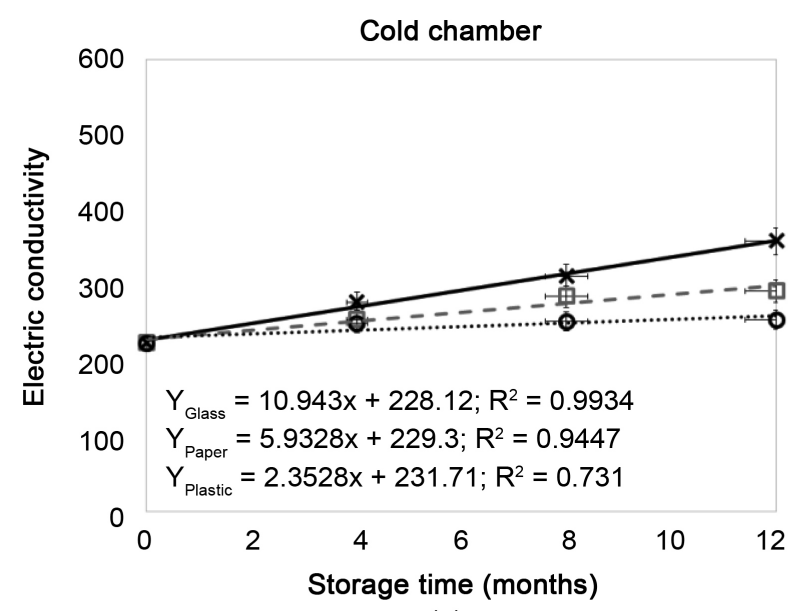

(a)

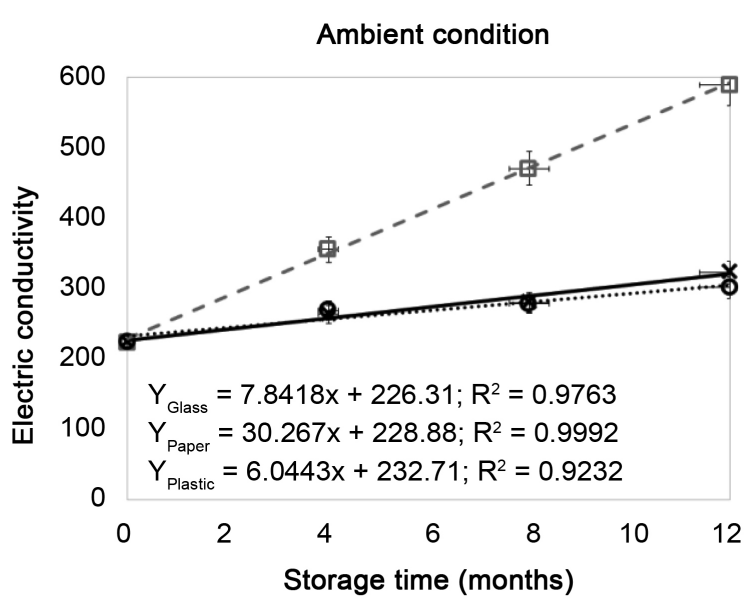

(b)

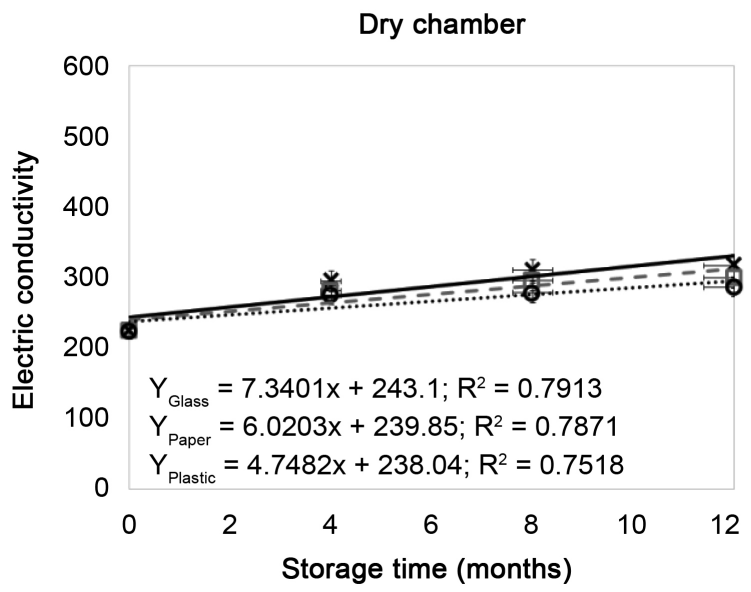

$\times$ Glass

$\square$ Paper

- Plastic

(c)

Figure 4. Electrical conductivity of chia seeds stored in three environments and three packages for a 12-month storage time.

quality in all evaluated parameters. The cold and dry chambers are the most suitable environments for a 12-month storage time since they maintained seeds physiological quality, regardless of the package.

This result is possibly associated with temperature and humidity variations under uncontrolled ambient conditions, which directly influenced the seeds due to their hygroscopicity. Reference [17] reported lower seeds viability of chia seeds stored in a permeable package, under laboratory conditions, when compared with a permeable or impermeable package under cold chamber conditions. The storage of the seeds under suitable conditions will positively influence the quality of the planting, helping the fast establishment of the crop and the reach of the desired plant stand, consequently potentiating the yield at the harvest time.

\section{Conclusion}

Chia seeds can be stored in a cold or dry chamber, in plastic, glass, or paper packages for a 12-month storage time, without damaging their physiological quality. 


\section{References}

[1] Chicco, A.G., D’Alessandro, M.E., Hein, G.J., Oliva, M.E. and Lombardo, Y.B. (2009) Dietary Chia Seed (Salvia hispanica L.) Rich in Alpha-Linolenic Acid Improves Adiposity and Normalises Hypertriacylglycerolaemia and Insulin Resistance in Dyslipaemic Rats. British Journal of Nutrition, 101, 41-50. https://doi.org/10.1017/S000711450899053X

[2] Sandoval-Oliveiros, M. and Paredes-López, O. (2013) Isolation and Characterization of Proteins from Chia Seeds (Salvia hispanica L.). Journal of Agricultural and Food Chemistry, 61, 193-201. https://doi.org/10.1021/jf3034978

[3] Ali, N.M., Yeap, S.K., Ho, W.Y., Beh, B.K., Tan, S.W. and Tan, S.G. (2012) The Promising Future of Chia, Salvia hispanica L. Journal of Biomedicine and Biotechnology, 2012, 1-9. https://doi.org/10.1155/2012/828139

[4] Barreto, A.D., Gutierrez, E.M.R., Silva, M.S., Silva, F.O., Silva, N.O.C., Lacerda, I.C.A., Labanca, R.A. and Araújo, R.L.B. (2016) Characterization and Bioaccessibility of Minerals in Seeds of Salvia hispanica L. American Journal of Plant Sciences, 7, 2323-2337. https://doi.org/10.4236/ajps.2016.715204

[5] Muñoz, L.A., Cobos, A., Diaz, O. and Aguilera, J.M. (2012) Chia Seeds: Microstructure, Mucilage Extraction and Hydration. Journal of Food Engineering, 108, 216-224. https://doi.org/10.1016/j.jfoodeng.2011.06.037

[6] Almeida, F.A.C., Jerônimo, E.S., Alves, N.M.C., Gomes, J.P. and Silva, A.S. (2010) Study of Techniques for the Storage of Five Oilseeds in Environmental and Cryogenic Conditions. Brazilian Journal of Agroindustrial Products, 12, 189-202. http://www.deag.ufcg.edu.br/rbpa/rev122/Art1220.pdf

[7] Pereira, M.D., Dias, D.C.F.S., Borges, E.E.L., Martins Filho, S., Dias, L.A.S. and Soriano, P.E. (2013) Physiological Quality of Physic Nut (Jatropha curcas L.) Seeds during Storage. Journal of Seed Science, 35, 21-27. https://doi.org/10.1590/S2317-15372013000100003

[8] Marcos-Filho, J. (2015) Seed Physiology of Cultivated Plants. 2nd Edition, ABRATES, Londrina, $660 \mathrm{p}$.

[9] José, S.C.B.R., Salomão, A.N., Costa, T.S.A., Silva, J.T.T.T. and Curi, C.C.S. (2010) Armazenamento de sementes de girassol em temperaturas subzero: Aspectos fisiológicos e bioquímicos. Revista Brasileira de Sementes, 32, 29-38. https://doi.org/10.1590/S0101-31222010000400004

[10] Vieira, H.D., Dardengo, A.O., Oliveira, M.T.R., Berbert, P.A. and Deminicis, B.B. (2017) Evaluation of Storage Potential of Jatropha curcas L. Seeds. American Journal of Plant Sciences, 8, 3013-3023.

https://www.scirp.org/Journal/PaperInformation.aspx?PaperID=80282 https://doi.org/10.4236/ajps.2017.812204

[11] Brasil Ministry of Agriculture and Agrarian Reform (2009) National Secretariat of Agricultural and Livestock Defense. Rules for Seed Analysis. National Department of Plant Protection. Coordination of Plant Laboratory, Brasília, DF, 399 p.

[12] Santana, A.M.S. and Carvalho, R.I.N. (2006) Viabilidade e capacidade de armazenamento de sementes de carqueja coletadas em três municípios no Paraná. Scientia Agraria, 7, 15-20. https://doi.org/10.5380/rsa.v7i1.7266

[13] Benedito, C.P., Ribeiro, M.C.C., Torres, S.B., Camacho, R.G.V., Soares, A.N.R. and Guimarães, L.M.S. (2011) Armazenamento de sementes de Catanduva (Piptadenia moniliformis Benth.) em diferentes ambientes e embalagens. Revista Brasileira de Sementes, 33, 1. https://doi.org/10.1590/S0101-31222011000100003 
[14] Graham, I.A. (2008) Seed Storage Oil Mobilization. Annual Review of Plant Biology, 59, 115-142. https://www.ncbi.nlm.nih.gov/pubmed/18444898 https://doi.org/10.1146/annurev.arplant.59.032607.092938

[15] Guedes, R.S., Alves, E.U., Gonçalves, E.P., Viana, J.S., França, P.R.C. and Santos, S.S. (2010) Qualidade fisiológica de sementes armazenadas de Amburana cearensis (Allemao) A.C. Smith. Semina: Ciências Agrárias, 31, 331-342.

http://www.redalyc.org/html/4457/445744096006/ https://doi.org/10.5433/1679-0359.2010v31n2p331

[16] Panobianco, M., Vieira, R.D. and Perecin, D. (2007) Electrical Conductivity as an Indicator of Pea Seed Aging of Stored at Different Temperatures. Scientia Agricola, 64, 119-124. https://doi.org/10.1590/S0103-90162007000200003

[17] Borba Filho, A.B. and Perez, S.C.J.G.A. (2009) Armazenamento de sementes de ipêbranco e ipê-roxo em diferentes embalagens e ambientes. Revista Brasileira de Sementes, 31, 259-269. https://doi.org/10.1590/S0101-31222009000100029 